\title{
Addendum
}

\section{Public Health, Social Medicine and Disease Control: Medical Services, Maternal Care and Sexually Transmitted Diseases in Former Portuguese West Africa (1920-63) - ADDENDUM}

\author{
PHILIP J. HAVIK \\ doi:10.1017/mdh.2018.44, Published online by Cambridge University Press, \\ 07 September 2018
}

The above article was originally submitted to Cambridge University Press with some missing funding information. This information is as follows:

The author would like to acknowledge the financial support of the Fundacão para a Ciência e Tecnologia (FCT) in Lisbon (Research Project IF/01130/2013/CP1165/CT0002), and thank anonymous referees for their insightful comments and Alexander Metcalf for his diligence. ${ }^{1}$

\footnotetext{
${ }^{1}$ P.J. Havik, 'Public Health, Social Medicine and Disease Control: Medical Services, Maternal Care and Sexually Transmitted Diseases in Former Portuguese West Africa (1920-63)', Medical History, 62 (2018), 485-506.
} 